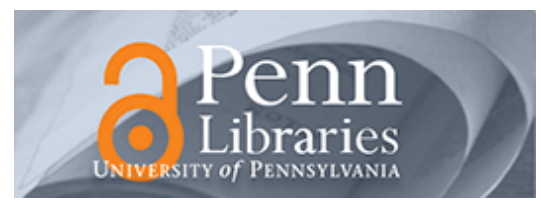

University of Pennsylvania

ScholarlyCommons

\title{
Cost of Capital for Pharmaceutical, Biotechnology, and Medical Device Firms
}

Scott E. Harrington

University of Pennsylvania

Follow this and additional works at: https://repository.upenn.edu/hcmg_papers

Part of the Biotechnology Commons, Corporate Finance Commons, Equipment and Supplies Commons, Health and Medical Administration Commons, Pharmacoeconomics and Pharmaceutical Economics Commons, and the Technology and Innovation Commons

\section{Recommended Citation (OVERRIDE)}

Harrington, S.E. (2012). Cost of Capital for Pharmaceutical, Biotechnology, and Medical Device Firms. In Danzon, P.M. \& Nicholson, S. (Eds.), The Oxford Handbook of the Economics of the Biopharmaceutical Industry, (pp. 75-99). New York: Oxford University Press.

This paper is posted at ScholarlyCommons. https://repository.upenn.edu/hcmg_papers/5

For more information, please contact repository@pobox.upenn.edu. 


\title{
Cost of Capital for Pharmaceutical, Biotechnology, and Medical Device Firms
}

\begin{abstract}
This article provides new estimates of systematic risk and the cost of equity capital for the pharmaceutical, biotechnology, and medical device sectors. The main analysis employs data for pharmaceutical, biotechnology, and medical device firms with publicly traded stock on US exchanges (including foreign-owned firms) with at least $\$ 100$ million of market capitalization during the periods 2001-2005 and 2006-2008. Two frameworks are used for estimating firms' risk and the cost of equity capital: the capital asset pricing model (CAPM) and the empirically driven three risk-factor model of Fama and French (the F-F model). The article is organized as follows. The first section briefly reviews prior work and discusses the likely relation between the cost of equity capital and R\&D intensity. The next section outlines the CAPM and F-F models and their empirical implementation. The data and samples are discussed in the third section. The fourth section presents beta and cost of equity capital estimates for equally weighted portfolios formed by sector and by sector and firm size. The fifth section presents results concerning the relationship between individual firm betas and R\&D intensity, and it is followed by a final concluding section.
\end{abstract}

\section{Keywords}

systemic risk, equity capital cost, pharmaceutical industry, biotechnology industry, medical device industry, capital asset pricing model, risk-factor model

\section{Disciplines}

Biotechnology | Corporate Finance | Equipment and Supplies | Health and Medical Administration | Pharmacoeconomics and Pharmaceutical Economics | Technology and Innovation 


\section{Oxford Handbooks Online}

\section{Cost of Capital for Pharmaceutical, Biotechnology, and Medical Device Firms a}

Scott E. Harrington

The Oxford Handbook of the Economics of the Biopharmaceutical Industry

Edited by Patricia M. Danzon and Sean Nicholson

Print Publication Date: Apr 2012

Subject: Economics and Finance, Health, Education, and Welfare, Financial Economics

Online Publication Date: Sep 2012 DOI: 10.1093/oxfordhb/9780199742998.013.0004

\section{Abstract and Keywords}

This article provides new estimates of systematic risk and the cost of equity capital for the pharmaceutical, biotechnology, and medical device sectors. The main analysis employs data for pharmaceutical, biotechnology, and medical device firms with publicly traded stock on US exchanges (including foreign-owned firms) with at least \$100 million of market capitalization during the periods 2001-2005 and 2006-2008. Two frameworks are used for estimating firms' risk and the cost of equity capital: the capital asset pricing model (CAPM) and the empirically driven three risk-factor model of Fama and French (the F-F model). The article is organized as follows. The first section briefly reviews prior work and discusses the likely relation between the cost of equity capital and R\&D intensity. The next section outlines the CAPM and F-F models and their empirical implementation. The data and samples are discussed in the third section. The fourth section presents beta and cost of equity capital estimates for equally weighted portfolios formed by sector and by sector and firm size. The fifth section presents results concerning the relationship between individual firm betas and R\&D intensity, and it is followed by a final concluding section.

Keywords: systemic risk, equity capital cost, pharmaceutical industry, biotechnology industry, medical device industry, capital asset pricing model, risk-factor model

THE investment, financing, and risk management decisions of pharmaceutical, biotechnology, and medical device firms are fundamentally important to the development and availability of innovative treatments to enhance health outcomes and the quality of life. Economically efficient investment, including research and development (R\&D), requires undertaking projects with positive net present value (i.e., projects for which the discounted value of expected net cash flows is positive, where the discount rate reflects 


\section{Cost of Capital for Pharmaceutical, Biotechnology, and Medical Device Firms}

investors' opportunity cost of capital). The cost of capital therefore has significant effects on investment decisions. It also affects the minimum product prices that are required to make basic research and particular $R \& D$ projects economically attractive.

Given long R\&D cycles and relatively low scientific success rates for individual projects, the effects of the cost of capital on investment decisions can be particularly large for the pharmaceutical, biotechnology, and medical device sectors. Because firms in these sectors are primarily financed by equity (common equity issues and retained earnings), as opposed to debt, the relevant cost of capital for investment decisions is dominated by the cost of equity capital (see, e.g., Myers and Shyam-Sunder 1996). Estimates of the cost of equity capital and understanding (p. 76) of factors that influence the cost of equity are therefore highly relevant to project development and policy issues, including drug and device pricing and measurement of the average cost of developing a new drug or device (e.g., DiMasi et al. 2003; DiMasi and Grabowski 2007; Vernon et al. 2010).

This study provides new estimates of systematic risk and the cost of equity capital for the pharmaceutical, biotechnology, and medical device sectors. The main analysis employs data for pharmaceutical, biotechnology, and medical device firms with publicly traded stock on US exchanges (including foreign-owned firms) with at least \$100 million of market capitalization during the periods 2001-2005 and 2006-2008. Two frameworks are used for estimating firms' risk and the cost of equity capital: the capital asset pricing model (CAPM) and the empirically driven three risk-factor model of Fama and French (FF model) (Fama and French 1992, 1993).

The CAPM is widely used by corporations, investment banks, and portfolio managers in valuation and capital budgeting. It is based on the simple notion that investors who are able to diversify at low cost will demand compensation only for bearing nondiversifiable risk. The CAPM posits that the risk premium required by investors for holding a particular security will depend on the sensitivity of the security's return to returns on the market portfolio of risky assets, as measured by the security's "beta." Beta is a measure of a security's market risk that cannot be diversified away by combining it with other securities in a portfolio.

The CAPM assumes a single market risk factor. The F-F model was developed in response to evidence that, controlling for market beta, historical mean returns on stocks for small firms were higher than for large firms and historical mean returns for stocks with high ratios of book-to-market equity ("value" stocks) were higher than for stocks with low book-to-market equity ("growth" or "glamour" stocks). The F-F model posits that two nondiversifiable risk factors affect the required return on a security in addition to its market risk: (1) a risk factor related to firms' market capitalization (the size factor), and (2) a risk factor related to firms' ratio of book value of equity capital to the market value of equity capital (the book-to-market factor). A firm's cost of equity capital depends on its market, size, and book-to-market betas and the risk premia associated with each risk factor. Although the F-F model is less widely used in valuation and capital budgeting than 


\section{Cost of Capital for Pharmaceutical, Biotechnology, and Medical Device Firms}

the CAPM, it is often used in comparison with the CAPM. In addition, many investment analysts employ cost of equity capital estimates that incorporate a size factor if not both a size and a book-to-market factor.

This study's empirical analysis focuses on possible differences in risk and the associated cost of equity capital across the pharmaceutical, biotechnology, and device sectors and between large and small firms within each sector. It also provides evidence of the relationship between firms' risk, cost of equity capital, and intensity of $R \& D$ expenditures, as measured by the ratio of R\&D to total revenues ("sales"). Prior work (discussed later) has emphasized that whereas technical uncertainty associated with success or failure during product development and approval is likely diversifiable, expected future $R \& D$ expenditures for a given project create a form of leverage analogous to operating and financial leverage. That leverage, which declines as the (p. 77) project moves through development, increases the systematic risk that arises from correlation between the project's projected commercial value conditional on success and underlying risk factors priced by investors, such as market risk.

There are four principal findings from the empirical analysis. First, R\&D intensity is positively related to market betas and thus to the estimated cost of equity capital, after controlling for firms' principal sector of operations (pharmaceutical, biotechnology, or device). Second, the choice of model matters. The CAPM and F-F models can produce materially different estimates of the cost of equity capital. In particular, the results for the F-F model imply a size-related risk premium in the cost of equity capital for smaller firms in each sector. Third, after controlling for R\&D intensity, average market betas can differ significantly across sectors. Biotech firms had significantly higher market betas than pharmaceutical firms during the period 2001-2005. Device firms had significantly higher betas than pharmaceutical firms during 2006-2008. Fourth, the time period matters, as implied by the results of this study and by a large negative and significant average bookto-market beta value for large biotech firms during 2001-2005, which significantly lowered the estimated cost of capital during that period but did not persist during 20062008.

These results were obtained from data for publicly-traded firms with at least $\$ 100$ million of market capitalization at the beginning of the sample periods. The cost of equity capital is usually higher, on average, for smaller publicly-traded firms and privately held firms for at least two reasons (e.g., Cockburn and Lerner 2009). First, investors are likely to require a higher expected return for smaller or privately held firms as compensation for the lack of liquidity from investing in such firms (e.g., Cockburn and Lerner). Second, smaller and privately held firms usually have a single compound or a few compounds in early stages of development, which results in high R\&D intensity and CAPM betas.

The first section that follows briefly reviews prior work and discusses the likely relation between the cost of equity capital and R\&D intensity. The next section outlines the CAPM and F-F models and their empirical implementation. The data and samples are discussed in the third section. The fourth section presents beta and cost of equity capital estimates 
for equally weighted portfolios formed by sector and by sector and firm size. The fifth section presents results concerning the relationship between individual firm betas and $R \& D$ intensity, and it is followed by a final concluding section.

\section{Prior Work}

Enormous theoretical and empirical literatures have considered the cost of capital in general and the cost of equity capital in particular. Much of this research addresses the CAPM and the F-F models, including their ability to (p. 78) explain cross-sectional stock returns (see, e.g., Fama and French 1992, 1993, 2006). Although much of this work castes doubt on its empirical veracity, the CAPM remains the most widely used method in practice for estimating the cost of capital.

The question of whether size and book-to-market factors in returns are persistent and are related to underlying priced risk factors has been extensively debated, including whether historical size-related return premia compensate for risk related to illiquidity or financial distress (see van Dijk 2010) and whether historical book-to-market-related return premia compensate for risk related to earnings volatility or financial distress.

Studies that have employed the CAPM or F-F model to estimate the cost of equity capital for pharmaceutical and biotechnology firms are summarized in Table 4.1. ${ }^{1}$ The CAPM beta and cost of capital estimates are fairly stable across studies and time periods, with no obvious secular trend. The results suggest higher CAPM betas for biotechnology firms and smaller pharmaceutical firms and positive F-F size betas for the small biotechnology firms and pharmaceutical firms. The analysis in this chapter extends these studies by considering relatively large samples of biotechnology, pharmaceutical, and device firms; including the analysis of post-2005 data; and specifically considering the relationship between beta estimates, cost of capital, and R\&D intensity at the firm level.

As summarized in Table 4.1, Grabowski and Vernon (1990) and DiMasi et al. 1991) utilized a real cost of capital estimate of 9 percent assuming an average CAPM beta of 1.0 based on beta estimates using data from the 1970s to the mid-1980s. The US Congress' Office of Technology Assessment (1993) reported an average pharmaceutical firm beta of 0.90 based on annual estimates for 20 to 25 firms during the period 1975-1987. Myers and Shyam-Sunder (1996) provided CAPM-based cost of capital estimates for large pharmaceutical firms as of 1980, 1985, and 1990. They reported mean CAPM betas of $0.98,0.70$, and 1.04 for the 1975-1979, 1981-1985, and 1985-1989 periods, respectively. They also reported an average beta of 1.54 using 1984-1988 data for seven small pharmaceutical and biotechnology firms.

Myers and Howe (1997) report an average CAPM beta of 1.05 for 13 large pharmaceutical firms using data for 1989-1993 and an average beta of 1.43 using annual data on weekly returns during 1986-1992 for 39 biotechnology firms with traded stock 
throughout the period. DiMasi et al. (2003) used the Myers and Shyam-Sunder, Myers and Howe, and updated beta estimates to estimate the cost of capital and resulting opportunity costs for drugs in development.

Golec and Vernon (2007) used the F-F model to estimate cost of capital for samples of pharmaceutical and biotechnology firms using 1982-2005 data. The average market betas were 0.92 for pharmaceuticals and 1.06 for biotechnology (p. 79) (p. 80) (p. 81) firms. The F-F size betas were large and significant for both samples, especially for biotechs, increasing the estimated cost of capital. The book-to-market factor betas were close to zero and insignificant for both sectors. Vernon et al. (2010) compared cost of capital estimates obtained using the CAPM and F-F models for pharmaceutical firms with 3 to 10 years of returns data ending in 1980 and 1986. The F-F cost of capital estimates were 300 to 600 basis points greater using the F-F model due to large estimated size betas. 
Table 4.1 Prior studies of pharmaceutical and biotechnology firms' cost of capital

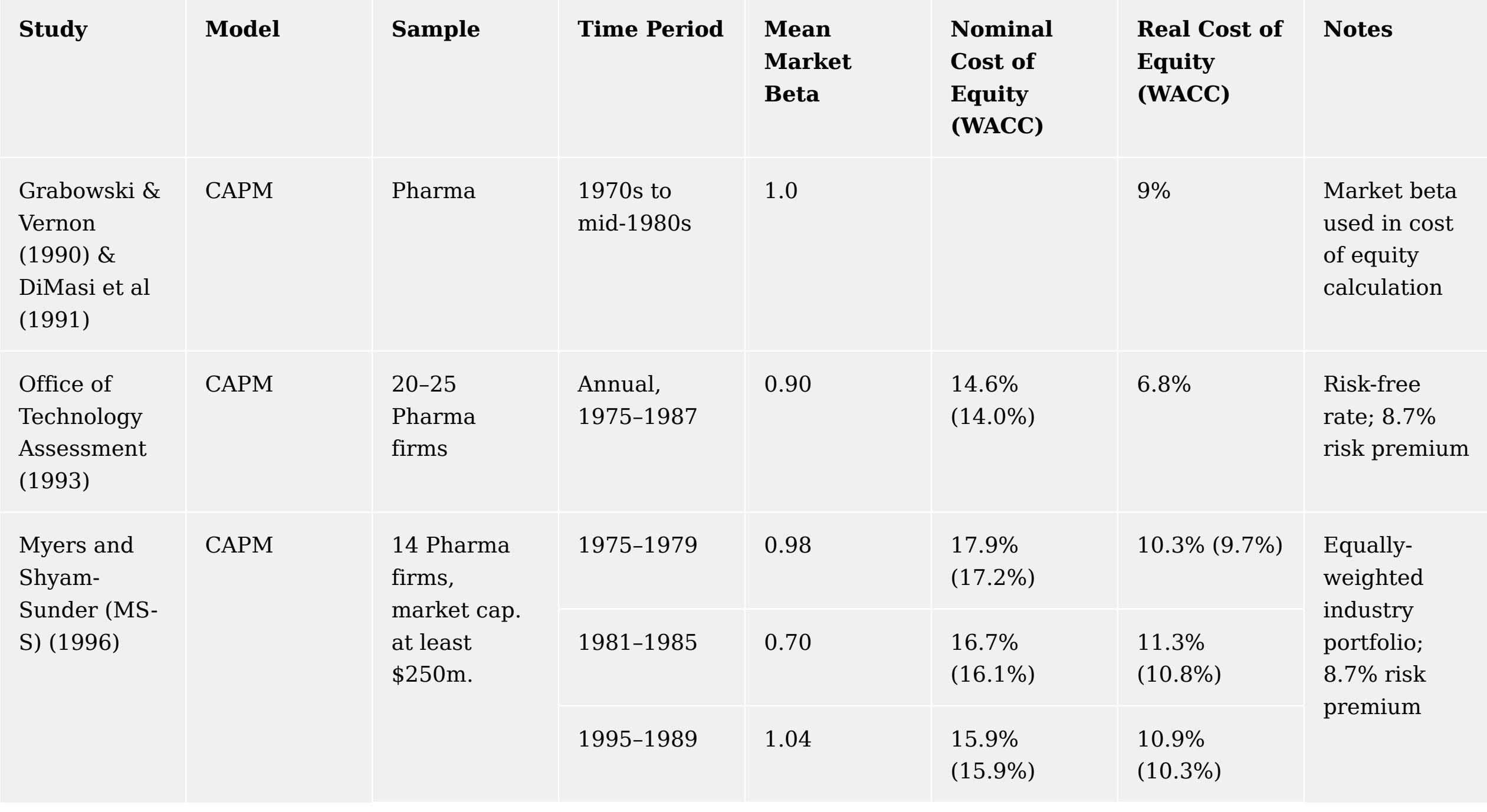




\begin{tabular}{|c|c|c|c|c|c|c|c|}
\hline & & $\begin{array}{l}7 \text { Small } \\
\text { pharma } \& \\
\text { biotech firms }\end{array}$ & 1984-1988 & 1.54 & $\begin{array}{l}21.1 \% \\
(19.1 \%)\end{array}$ & $\begin{array}{l}16.1 \% \\
(14.1 \%)\end{array}$ & \\
\hline \multirow[t]{2}{*}{$\begin{array}{l}\text { Myers \& } \\
\text { Howe (MH) } \\
(1997)\end{array}$} & \multirow[t]{2}{*}{ CAPM } & $\begin{array}{l}13 \text { Pharma } \\
\text { firms }\end{array}$ & 1989-1993 & 1.05 & $\begin{array}{l}14.2 \% \\
(13.7 \%)\end{array}$ & $\begin{array}{l}11.2 \% \\
(10.7 \%)\end{array}$ & $\begin{array}{l}\text { Equally- } \\
\text { weighted; } \\
8.7 \% \text { risk } \\
\text { premium }\end{array}$ \\
\hline & & $\begin{array}{l}39 \text { Biotechs } \\
\text { traded since } \\
1986\end{array}$ & $\begin{array}{l}\text { Annual, } \\
\text { 1986-1992 }\end{array}$ & 1.43 & & & $\begin{array}{l}\text { Estimated by } \\
\text { Shyam- } \\
\text { Sunder }\end{array}$ \\
\hline \multirow{4}{*}{$\begin{array}{l}\text { DiMasi et al. } \\
(2003)\end{array}$} & \multirow[t]{4}{*}{ CAPM } & \multirow{4}{*}{$\begin{array}{l}\text { MS-S and } \\
\text { MH; updated } \\
\text { through } \\
2000\end{array}$} & 1985 & 0.98 & $16.1 \%$ & $10.8 \%$ & \\
\hline & & & 1990 & 0.70 & $15.1 \%$ & $10.6 \%$ & \\
\hline & & & 1994 & 1.04 & $14.2 \%$ & $11.1 \%$ & \\
\hline & & & 2000 & n.a. & $15.0 \%$ & $11.9 \%$ & \\
\hline $\begin{array}{l}\text { Golec \& } \\
\text { Vernon } \\
(2007)\end{array}$ & $\mathrm{F}-\mathrm{F}$ & Pharma & 1982-2005 & 0.92 & $14.5 \%$ & & $\begin{array}{l}0.8 \text { size beta; } \\
0.02 \mathrm{~B} / \mathrm{M} \\
\text { beta }\end{array}$ \\
\hline
\end{tabular}




\begin{tabular}{|c|c|c|c|c|c|c|c|}
\hline & & Biotech & & 1.06 & $16.2 \%$ & & $\begin{array}{l}1.3 \text { size beta; } \\
-0.10 \mathrm{~B} / \mathrm{M} \\
\text { beta }\end{array}$ \\
\hline \multirow{4}{*}{$\begin{array}{l}\text { Vernon et al. } \\
(2010)\end{array}$} & CAPM & Pharma & Ending 1980 & & & $11.0 \%$ & \\
\hline & & years of data & Ending 1986 & & & $10.4 \%$ & \\
\hline & $\mathrm{F}-\mathrm{F}$ & & Ending 1980 & & & $14.4 \%$ & $\begin{array}{l}0.66 \text { size } \\
\text { beta }\end{array}$ \\
\hline & & & Ending 1986 & & & $16.6 \%$ & $\begin{array}{l}0.99 \text { size } \\
\text { beta }\end{array}$ \\
\hline
\end{tabular}

Abbreviations: B/M, book-to-market; CAPM, capital asset pricing model; F-F, Fama and French model; n.a., not applicable; WACC, weighted average cost of capital. 
Myers and Shyam-Sunder (1996) explained why, given the implicit leverage associated with $R \& D$, systematic risk will likely increase with $R \& D$ intensity and be greater for earlystage projects compared with more mature projects. Myers and Howe (1997) provided a detailed explanation of how the quasi-fixed nature of planned $R \& D$ expenditures produces a form of leverage analogous to operating leverage associated with fixed operating costs and financial leverage associated with debt financing. They explained how variation in expected $R \& D$ over the lifetime of a project will cause $R \& D$ leverage and systematic risk to decline as a drug moves through the development process, giving rise to what they term the "risk-return staircase" in drug development.

Myers and Shyam-Sunder (1996) and Myers and Howe (1997) also observed that a positive relationship between $R \& D$ intensity and risk is implied by option pricing models. Berk et al. (2004) developed a dynamic model of multistage investment to illustrate how risk associated with ultimate cash flows in $R \& D$-intensive ventures has a systematic component even though technical risk about advancement of a project is diversifiable. They viewed risky, R\&D ventures as compound options with systematic uncertainty. They explained how an R\&D-intensive project can be viewed as a series of compound options on the underlying cash flows of the project, with the strike price equivalent to the expected future investment in $R \& D$. The risk premium on the project decreases if the project advances and, as a result, becomes more "in the money." When a development stage is completed successfully, expected future investment drops, thus reducing the strike price and systematic risk of the project.

Myers and Shyam-Sunder (1996) conjectured that the higher mean beta they reported for small biotech and pharmaceutical companies compared with large pharmaceutical companies is consistent with an association between high R\&D expenditures and high systematic risk. In an analysis of the potential effects of the Clinton administration's proposed Health Security Act of 1993 on pharmaceutical and biotechnology firms' stock prices and R\&D spending, Golec et al. (2005) used the CAPM to estimate abnormal stock returns and reported higher average CAPM betas (estimated with 1992-1993 data) for firms with higher average ratios of R\&D to assets during 1989-1991. ${ }^{2}$ (p. 82)

\section{The CAPM and Fama-French Models}

The CAPM and F-F models are expected-return beta representations of linear factor pricing models. ${ }^{3}$ The basic formulation of such a models is (1)

$$
E\left(R_{j}\right)=\gamma+\beta_{j 1} \lambda_{1}+\beta_{j 2} \lambda_{2}+\ldots+\beta_{j K} \lambda_{K}, j=1,2, \ldots, N
$$

where $E\left(R_{j}\right)$ is the expected return on asset $j, \gamma$ is the riskless rate of interest (or, if no riskless rate exists, the expected return on a zero-beta asset or portfolio), $\lambda_{\mathrm{k}}(k=1,2, \ldots$, 
$K)$ is the expected risk premium for the $k$ th risk factor, and $\beta_{\mathrm{jk}}(j=1,2, \ldots, N ; k=1,2, \ldots$, $K)$ is the sensitivity of asset $j$ 's return to the $k$ th risk factor.

The $k$ underlying risk factors serve as a proxy for changes in the marginal utility of consumption and represent sources of risk that cannot be eliminated via portfolio diversification. Equation 1 portrays the fundamental principle that assets with greater risk sensitivities must provide investors with higher expected returns; that is, they tend to provide greater payoffs when consumption is high and the marginal utility of consumption is low, and smaller payoffs when consumption is low and the marginal utility of consumption is high.

The single risk factor in the CAPM is the return on the market portfolio of risky assets. With a riskless interest rate, $R_{F}$, each asset's expected return is (2)

$$
E\left(R_{j}\right)_{C A P M}=R_{F}+\beta_{j} E\left(R_{M}-R_{F}\right), j=1,2, \ldots, N
$$

where $\beta_{\mathrm{j}}$ is the asset's market ("CAPM") beta, $E\left(R_{M}-R_{F}\right)$ is the expected excess return on the market portfolio (the "market risk premium"). $E\left(R_{j}\right)_{C A P M}$ is the xpected required return (opportunity cost of equity capital) for stock $j$ given its risk, $\beta_{j}$. If $\beta_{j}$ varies across assets in relation to some variable, $x_{j}$, the cost of capital will vary according to the following equation:

$$
\frac{\partial E\left(R_{j}\right)_{C A P M}}{\partial x_{j}}=E\left(R_{M}-R_{F}\right) \frac{\partial \beta_{j}}{\partial x_{j}} .
$$

(p. 83) The F-F model posits three risk factors: (1) the excess return on the market portfolio, (2) the excess return on a portfolio of "small" stocks versus "big" stocks, and (3) the excess return on a portfolio of stocks with "high" ratios of book equity to market equity (book-to-market ratios) versus stocks with "low" book-to-market ratios. The expected return for asset $j$ is (3)

$$
E\left(R_{j}\right)_{F F}=R_{F}+\beta_{j, M K T-R F} E\left(R_{M}-R_{F}\right)+\beta_{j, S M B} E\left(R_{S}-R_{B}\right)+\beta_{j, H M L} E\left(R_{H}-R_{L}\right),
$$

where $\beta_{\mathrm{j}, \mathrm{MKT}-\mathrm{RF}}$ is the asset's excess market return beta (analogous to its CAPM beta), and $R_{S}, R_{B}, R_{H}$, and $R_{L}$ are returns on the relevant portfolios of small, big, high book-tomarket, and low book-to-market stocks, respectively (see Fama and French 1993). If the F-F betas vary in relation to some variable, $x_{j}$, the cost of capital will likewise vary according to the following equation:

$$
\frac{\partial E\left(R_{j}\right)_{H F}}{\partial x_{j}}=E\left(R_{M}-R_{F}\right) \frac{\partial \beta_{j, M K T-R F}}{\partial x_{j}}+E\left(R_{s}-R_{B}\right) \frac{\partial \beta_{j, S M B}}{\partial x_{j}}+E\left(R_{H}-R_{L}\right) \frac{\partial \beta_{j, H M L}}{\partial x_{j}} .
$$


Given equation 2, an estimate of a security's or a portfolio's CAPM beta can be obtained by using least squares to estimate the following model with returns data for a given period: (4)

$$
R_{j t}-R_{F t}=\alpha_{j, C A P M}+\beta_{j, C A P M}\left(R_{M t}-R_{F t}\right)+\varepsilon_{j t} .
$$

Similarly, given equation 3, estimates of F-F betas can be obtained by estimating the following: (5)

$$
\begin{aligned}
R_{j t}-R_{F t}= & \alpha_{j, F F}+\beta_{j, M K T-R F}\left(R_{M t}-R_{F t}\right)+\beta_{j, S M B}\left(R_{S t}-R_{B t}\right) \\
& +\beta_{j, H M L}\left(R_{H t}-R_{L t}\right)+\varepsilon_{j t} .
\end{aligned}
$$

Given beta estimates from equations 4 and 5, cost of equity capital estimates can be generated as a function of assumed values for the risk-free interest rate and market, size factor, and book-to-market factor risk premia. If, for example, the assumed risk-free rate is 5 percent and the assumed market, size factor, and book-to-market factor risk premia are 7 percent, 3 percent, and 4 percent, respectively, cost of equity capital estimates would be obtained as follows:

$$
\hat{k}_{j, C A P M}=0.05+0.07 \widehat{\beta}_{j, C A P M}
$$

and

$$
\hat{k}_{j, F F}=0.05+0.07 \hat{\beta}_{j, M K T-R F}+0.03 \hat{\beta}_{j, S M L}+0.04 \hat{\beta}_{j, H M L} .
$$

Assumed risk premia typically are based on historical mean excess returns for the relevant factor portfolios. (p. 84)

\section{Data and Samples}

This study focuses on estimates of CAPM and F-F betas using monthly returns data for two time periods: 2001-2005 (60 monthly returns) and 2006-2008 (36 monthly returns). The 2001-2005 period occurred after the technology stock ("dot.com") boom and bust and predated the subprime mortgage and financial crisis that began in 2006 and accelerated during 2007-2008. The 2006-2008 period encompassed the crisis. 
The following criteria were used to select sample firms in each period:

- The firm's stock was included in the S\&P Composite 1500 index and was identified in Standard \& Poor's Industry Survey at the end of the period for pharmaceutical firms, biotechnology firms, or medical device firms (health care products and supplies).

- Complete monthly returns were available from the Center for Research in Security Prices (CRSP) for the sample period.

- The firm was included in the Compustat database each year during the sample period and had nonmissing data for R\&D expenses.

- The firm had market capitalization of $\$ 100$ million or more at the beginning of the sample period. ${ }^{4}$

These restrictions resulted in samples of 100 and 99 firms for 2001-2005 and 2006-2008, respectively. The firms were classified as primarily pharmaceutical, biotechnology, or medical device companies using the classification in Standard \& Poor's Industry Survey. ${ }^{5}$ Firms were then classified into large- and small-firm subgroups within each sector based on whether their market capitalization was above or below the median value for the entire sample at the beginning of the sample period (\$2.51 billion for 2001-2005 and \$2.48 billion for 2006-2008). ${ }^{6}$ Monthly returns (including dividends) for each firm were obtained from the CRSP through Wharton Research Data Services (WRDS). Monthly returns in excess of the monthly Treasury bill yield ("excess returns") were calculated for each security. The riskfree rates were the monthly Treasury bill yields. Monthly excess returns on the valueweighted portfolio of all securities traded on the NYSE, AMEX, and NASDAQ exchanges and on size-based and book-to-market (p. 85) ratio-based portfolios were obtained from WRDS (and are also available from Kenneth French's website).

$R \& D$ expense (net of acquired in-process $R \& D$ ), total revenues (sales), and other financial data were obtained from the Compustat Annual Fundamentals files, also available through WRDS. The average lagged (one-year) ratio of a firm's annual R\&D expense to its annual sales during the sample period was calculated as a measure of its average $R \& D$ intensity. A few values greater than 1 were truncated at 1 for each sample. ${ }^{7}$ The average lagged ratio of a firm's long-term debt to value (long-term debt plus convertible debt plus preferred stock plus market value of equity) and the average lagged ratio of the firm's book value of equity to market value of equity also were calculated for each firm in each period.

Table 4.2 shows sample sizes, mean monthly excess returns, and mean and median values of market capitalization, $\mathrm{R} \& \mathrm{D} /$ sales, long-term debt/value, and book-to-market equity for each sector and sector-size subgroup for the 2001-2005 and 2006-2008 samples. Consistent with the general upward trend in stock prices, the mean excess returns were positive for each category during 2001-2005, with large excess returns for small pharmaceutical and small device firms. During the 2006-2008 period, as the overall market declined sharply in the latter half of 2008, the excess returns were negative for each group except small biotech and small device firms. Relatively few pharmaceutical firms had market capitalizations lower than the overall sample median value during each 
period, whereas the device firm samples included many small firms. The giant pharmaceutical firms caused the mean values of market capitalization for the overall pharmaceutical and large pharmaceutical groups to be much greater than the medians.

During 2001-2005, the mean and median values of R\&D/sales were much larger for biotechnology firms than for pharmaceutical and medical device firms. For example, the median of R\&D/sales for the overall biotech group was 33 percent, compared with 10 percent for pharmaceutical firms and 7 percent for device firms. During 2006-2008, however, the mean and median $\mathrm{R} \& \mathrm{D} /$ sales ratios for the large biotech group were much lower than in 2001-2005, and the difference in R\&D intensity between large biotechnology firms and large firms in the other sectors narrowed considerably.

The mean and median values of book-to-market equity were roughly similar across groups and time periods. The mean and median values of long-term debt/value were low, just exceeding 10 percent for the small pharmaceutical group during 2006-2008. Because many firms in these sectors hold substantial cash and marketable securities, measures of net debt (total debt less cash and marketable securities) would be even lower (and negative for some firms). As a result of the minimal use of (p. 86) (p. 87) debt financing by most firms, the weighted-average cost of debt and equity capital will be approximately equal to the cost of equity capital. ${ }^{8}$ For that reason, this paper, like a number of previous studies, focused on the cost of equity capital. 
Table 4.2 Means and medians (in brackets) of selected characteristics of sample firms

\section{Pharmaceutical}

\begin{tabular}{|c|c|c|c|c|c|c|c|c|c|}
\hline $\begin{array}{l}\text { Study } \\
\text { Period }\end{array}$ & All & Large & Small & All & Large & Small & All & Large & Small \\
\hline \multicolumn{10}{|l|}{$\begin{array}{l}2001- \\
2005\end{array}$} \\
\hline $\begin{array}{l}\text { Number } \\
\text { of firms }\end{array}$ & 31 & 22 & 9 & 26 & 17 & 9 & 44 & 12 & 32 \\
\hline $\begin{array}{l}\text { Portfolio } \\
\text { mean } \\
\text { excess } \\
\text { return }\end{array}$ & $0.51 \%$ & $0.13 \%$ & $1.43 \%$ & $0.31 \%$ & $0.15 \%$ & $0.61 \%$ & $1.40 \%$ & $0.60 \%$ & $1.70 \%$ \\
\hline $\begin{array}{l}\text { Market } \\
\text { equity } \\
\text { (\$bill., } \\
12 / 31 / 00)\end{array}$ & $\begin{array}{l}\$ 40.2 \\
{[\$ 5.9]}\end{array}$ & $\begin{array}{l}\$ 56.2 \\
{[\$ 10.2]}\end{array}$ & $\begin{array}{l}\$ 1.0 \\
{[\$ 0.8]}\end{array}$ & $\begin{array}{l}\$ 8.6 \\
{[\$ 3.3]}\end{array}$ & $\begin{array}{l}\$ 12.6 \\
{[\$ 8.5]}\end{array}$ & $\begin{array}{l}\$ 1.2 \\
{[\$ 1.1]}\end{array}$ & $\begin{array}{l}\$ 4.6 \\
{[\$ 0.9]}\end{array}$ & $\begin{array}{l}\$ 14.6 \\
{[\$ 8.0]}\end{array}$ & $\begin{array}{l}\$ 0.8 \\
{[\$ 0.6]}\end{array}$ \\
\hline $\begin{array}{l}\text { R\&D/ } \\
\text { sales }^{*}\end{array}$ & $\begin{array}{l}0.179 \\
{[0.104]}\end{array}$ & $\begin{array}{l}0.162 \\
{[0.106]}\end{array}$ & $\begin{array}{l}0.221 \\
{[0.086]}\end{array}$ & $\begin{array}{l}0.466 \\
{[0.329]}\end{array}$ & $\begin{array}{l}0.511 \\
{[0.327]}\end{array}$ & $\begin{array}{l}0.382 \\
{[0.348]}\end{array}$ & $\begin{array}{l}0.090 \\
{[0.072]}\end{array}$ & $\begin{array}{l}0.073 \\
{[0.058]}\end{array}$ & $\begin{array}{l}0.097 \\
{[0.077]}\end{array}$ \\
\hline
\end{tabular}




\begin{tabular}{|c|c|c|c|c|c|c|c|c|c|}
\hline $\begin{array}{l}\text { Long- } \\
\text { term } \\
\text { debt/ } \\
\text { value }\end{array}$ & $\begin{array}{l}0.074 \\
{[0.041]}\end{array}$ & $\begin{array}{l}0.067 \\
{[0.048]}\end{array}$ & $\begin{array}{l}0.092 \\
{[0.041]}\end{array}$ & $\begin{array}{l}0.074 \\
{[0.043]}\end{array}$ & $\begin{array}{l}0.082 \\
{[0.064]}\end{array}$ & $\begin{array}{l}0.063 \\
{[0.030]}\end{array}$ & $\begin{array}{l}0.069 \\
{[0.034]}\end{array}$ & $\begin{array}{l}0.064 \\
{[0.048]}\end{array}$ & $\begin{array}{l}0.071 \\
{[0.032]}\end{array}$ \\
\hline $\begin{array}{l}\text { Book } \\
\text { equity/ } \\
\text { market } \\
\text { equity }\end{array}$ & $\begin{array}{l}0.279 \\
{[0.218]}\end{array}$ & $\begin{array}{l}0.306 \\
{[0.230]}\end{array}$ & $\begin{array}{l}0.215 \\
{[0.187]}\end{array}$ & $\begin{array}{l}0.280 \\
{[0.286]}\end{array}$ & $\begin{array}{l}0.259 \\
{[0.283]}\end{array}$ & $\begin{array}{l}0.318 \\
{[0.328]}\end{array}$ & $\begin{array}{l}0.270 \\
{[0.224]}\end{array}$ & $\begin{array}{l}0.264 \\
{[0.182]}\end{array}$ & $\begin{array}{l}0.272 \\
{[0.256]}\end{array}$ \\
\hline $\begin{array}{l}2006- \\
2008\end{array}$ & & & & & & & & & \\
\hline $\begin{array}{l}\text { Number } \\
\text { of firms }\end{array}$ & 28 & 21 & 7 & 29 & 14 & 15 & 42 & 15 & 27 \\
\hline $\begin{array}{l}\text { Portfolio } \\
\text { mean } \\
\text { excess } \\
\text { return }\end{array}$ & $-0.58 \%$ & $-0.66 \%$ & $-0.36 \%$ & $0.36 \%$ & $-0.55 \%$ & $0.42 \%$ & $-0.17 \%$ & $-0.51 \%$ & $0.01 \%$ \\
\hline $\begin{array}{l}\text { Market } \\
\text { equity } \\
\text { (\$bill., } \\
\text { 12/31/05) }\end{array}$ & $\begin{array}{l}\$ 40.8 \\
{[\$ 6.0]}\end{array}$ & $\begin{array}{l}\$ 54.7 \\
{[\$ 37.9]}\end{array}$ & $\begin{array}{l}\$ 1.2 \\
{[\$ 1.3]}\end{array}$ & $\begin{array}{l}\$ 12.8 \\
{[\$ 2.6]}\end{array}$ & $\begin{array}{l}\$ 24.5 \\
{[\$ 11.1]}\end{array}$ & $\begin{array}{l}\$ 0.9 \\
{[\$ 0.9]}\end{array}$ & $\begin{array}{l}\$ 4.2 \\
{[\$ 1.3]}\end{array}$ & $\begin{array}{l}\$ 10.0 \\
{[\$ 6.9]}\end{array}$ & $\begin{array}{l}\$ 0.9 \\
{[\$ 0.8]}\end{array}$ \\
\hline
\end{tabular}

Page 15 of 40

PRINTED FROM OXFORD HANDBOOKS ONLINE (www.oxfordhandbooks.com). (c) Oxford University Press, 2015. All Rights Reserved. Under the terms of the licence agreement, an individual user may print out a PDF of a single chapter of a title in Oxford Handbooks Online for personal use (for details see Privacy Policy).

Subscriber: University of Pennsylvania; date: 20 July 2017 


\begin{tabular}{|c|c|c|c|c|c|c|c|c|c|}
\hline $\begin{array}{l}\text { R\&D/ } \\
\text { sales }^{*}\end{array}$ & $\begin{array}{l}0.154 \\
{[0.150]}\end{array}$ & $\begin{array}{l}0.153 \\
{[0.152]}\end{array}$ & $\begin{array}{l}0.156 \\
{[0.124]}\end{array}$ & $\begin{array}{l}0.307 \\
{[0.194]}\end{array}$ & $\begin{array}{l}0.156 \\
{[0.157]}\end{array}$ & $\begin{array}{l}0.447 \\
{[0.321]}\end{array}$ & $\begin{array}{l}0.088 \\
{[0.062]}\end{array}$ & $\begin{array}{l}0.082 \\
{[0.062]}\end{array}$ & $\begin{array}{l}0.092 \\
{[0.067]}\end{array}$ \\
\hline $\begin{array}{l}\text { Long- } \\
\text { term } \\
\text { debt/ } \\
\text { value }\end{array}$ & $\begin{array}{l}0.096 \\
{[0.072]}\end{array}$ & $\begin{array}{l}0.088 \\
{[0.071]}\end{array}$ & $\begin{array}{l}0.118 \\
{[0.079]}\end{array}$ & $\begin{array}{l}0.082 \\
{[0.056]}\end{array}$ & $\begin{array}{l}0.077 \\
{[0.082]}\end{array}$ & $\begin{array}{l}0.087 \\
{[0.047]}\end{array}$ & $\begin{array}{l}0.065 \\
{[0.164]}\end{array}$ & $\begin{array}{l}0.063 \\
{[0.055]}\end{array}$ & $\begin{array}{l}0.066 \\
{[0.014]}\end{array}$ \\
\hline $\begin{array}{l}\text { Book } \\
\text { equity/ } \\
\text { market } \\
\text { equity }\end{array}$ & $\begin{array}{l}0.308 \\
{[0.295]}\end{array}$ & $\begin{array}{l}0.275 \\
{[0.215]}\end{array}$ & $\begin{array}{l}0.405 \\
{[0.356]}\end{array}$ & $\begin{array}{l}0.273 \\
{[0.238]}\end{array}$ & $\begin{array}{l}0.290 \\
{[0.264]}\end{array}$ & $\begin{array}{l}0.256 \\
{[0.185]}\end{array}$ & $\begin{array}{l}0.294 \\
{[0.259]}\end{array}$ & $\begin{array}{l}0.240 \\
{[0.206]}\end{array}$ & $\begin{array}{l}0.324 \\
{[0.264]}\end{array}$ \\
\hline
\end{tabular}

(*) Individual firm means were truncated at 1. 


\section{Beta and Cost of Capital Estimates}

\section{Historical Market Betas for US Pharmaceutical Companies}

To help place the study's results for the 2001-2005 and 2006-2008 samples in context and provide additional evidence on the historical pattern of pharmaceutical firms' betas, Figure 4.1 first plots average CAPM beta estimates obtained with 60 months of data for sample periods ending each month from December 1969 through December 2008. These "rolling" beta estimates are shown for two samples. The first sample includes all US publicly-traded firms with Standard Industrial Classification (SIC) code 2834 (Pharmaceutical Preparations). This sample includes generic as well as brand manufacturers and any biotechnology firms with that SIC code. It consists of 25 to 30 companies during 1965-1980 and grows to about 50 companies in 1980, 130 companies in 2005, and 180 companies in 2008. The second sample includes seven large companies with SIC code 2834 that had publicly-traded stock throughout the period 1965-2008: Abbott Labs, Baxter, Bristol Myers (Squibb), Merck, Pfizer, Schering Plough, and Wyeth (American Home). It also includes Forest Labs from December 1967 onward and Eli Lilly from September 1970 onward.

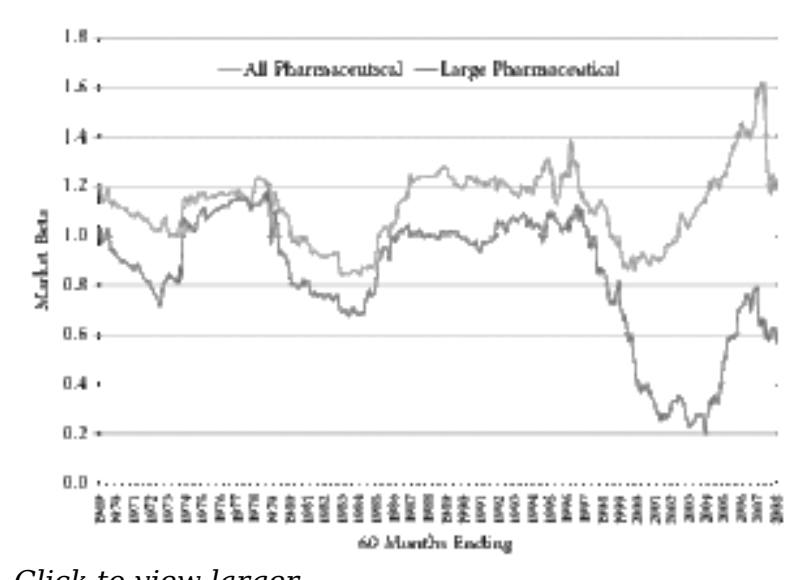

Click to view larger

Figure 4.1 Sixty-month rolling market betas for large US pharmaceutical companies and all publicly traded firms with Standard Industrial Classification (SIC) code 2834 (Pharmaceutical Preparations): December 1969 through December 2008.
The average CAPM beta estimates shown in Figure 4.1 exhibit considerable volatility over time. The average betas are larger for the sample of all pharmaceutical firms than for the large pharmaceutical firms. The difference between the samples increased in conjunction with the large increase in the number of relatively small, publiclytraded pharmaceutical firms during the past decade (most of which

were smaller than the size cutoff for inclusion in the 2001-2006 and 2005-2008 samples). The average betas decline substantially for sample periods that included the technology stock bubble and its aftermath during the late 1990s and early 2000s, especially for the large-firm sample. The average betas also declined during late 2007 (p. 88) and 2008 as 
pharmaceutical stocks performed relatively well during the run-up to and onset of the 2008 financial crisis.

\section{CAPM Betas}

Table 4.3 shows the results of using equation 4 to estimate CAPM betas for nine equallyweighted portfolios: three sector portfolios and six sector-size portfolios. Beta estimates for equally-weighted portfolios are mathematically equivalent to the arithmetic mean of beta estimates for the securities in the portfolio. A multivariate regression model (MVRM) was used to jointly estimate the equations for the three sectors and for the six sector-size portfolios. The MVRM produces estimates identical to estimating the model for each portfolio separately, but it permits tests of equality of betas across portfolios that reflect possible correlations in disturbances across the portfolios.

For the 2001-2005 sample, the CAPM beta estimate was much larger for biotechs (1.32) than for the pharmaceutical firms (0.69) and the device firms (0.66), and the differences were statistically significant at the 0.01 level. During 2006-2008, the CAPM beta estimate for the pharmaceutical portfolio was 0.61 . The large biotech beta dropped to 0.75 , and the overall biotech beta dropped to 0.97 . The beta estimate for the overall device portfolio was 0.89 . The biotech and device betas for 2006-2008 were significantly greater than the pharmaceutical beta at the 0.05 level (p. 89) (p. 90) but not significantly different from each other. The coefficient of determination $\left(R^{2}\right)$ for the small pharmaceutical portfolio for 2006-2008, which included only 7 firms, was only 14 percent. With the exception of the small pharmaceutical portfolio, the $R^{2}$ values were materially larger during 2006-2008 than during 2001-2005, especially for device firms. 
Table 4.3 CAPM model parameter estimates for equal-weighted sector/size-based portfolios using monthly returns*

\section{1-2005}

\begin{tabular}{|c|c|c|c|c|c|c|}
\hline Group & $\hat{\alpha}_{j, C A P M}$ & $\hat{\beta}_{j, C A P M}$ & R-sq. & $\widehat{\alpha}_{j, C A P M}$ & $\hat{\beta}_{j, C A P M}$ & R-sq. \\
\hline Pharmaceutical & $0.004(0.406)$ & $0.692(0.000)$ & $39.6 \%$ & $-0.000(0.952)$ & $0.611(0.000)$ & $52.0 \%$ \\
\hline Large & $0.000(0.080)$ & $0.650(0.000)$ & $41.7 \%$ & $-0.001(0.862)$ & $0.641(0.000)$ & $59.3 \%$ \\
\hline Small & $0.132(0.100)$ & $0.795(0.000)$ & $25.3 \%$ & $0.001(0.916)$ & $0.521(0.024)$ & $14.2 \%$ \\
\hline Biotechnology & $0.001(0.867)$ & $1.319(0.000)$ & $46.2 \%$ & $0.008(0.217)$ & $0.971(0.000)$ & $58.6 \%$ \\
\hline Large & $-0.000(0.987)$ & $1.302(0.000)$ & $41.8 \%$ & $0.001(0.807)$ & $0.752(0.000)$ & $56.3 \%$ \\
\hline Small & $0.004(0.638)$ & $1.350(0.000)$ & $42.6 \%$ & $0.015(0.132)$ & $1.175(0.000)$ & $49.5 \%$ \\
\hline Device & $0.013(0.001)$ & $0.662(0.000)$ & $52.2 \%$ & $0.006(0.152)$ & $0.889(0.000)$ & $73.7 \%$ \\
\hline Large & $0.005(0.230)$ & $0.606(0.000)$ & $40.3 \%$ & $0.002(0.585)$ & $0.836(0.000)$ & $69.4 \%$ \\
\hline Small & $0.016(0.001)$ & $0.693(0.000)$ & $42.5 \%$ & $0.008(0.100)$ & $0.919(0.000)$ & $69.0 \%$ \\
\hline
\end{tabular}

2006-2008

$0.016(0.001)$ 
(*) The regression equation is $R_{j t}-R_{F t}=\alpha_{j, C A P M}+\beta_{j, C A P M}\left(R_{M t}-R_{F t}\right)+\varepsilon_{j t}$. Subsamples include firms in the sector with market value of equity above (Large) or below (Small) the median value for all sample firms at the beginning of the sample period. Two-tailed $p$ values are shown in parentheses. Bold values are significant at the 0.05 level. 
The much higher biotech beta for 2001-2005 is consistent with the much higher R\&D intensity for biotechs during this time period (see Table 4.2). The drop in biotech portfolio betas for 2006-2008 coincided with reductions in R\&D intensity during this period compared with 2001-2005. The increases in the device portfolio betas during the 20062008 period compared with 2001-2005 were not accompanied by any increase in R\&D intensity.

The estimated "alphas" (intercepts) shown in Table 4.3 were generally positive, especially for the 2001-2005 period. ${ }^{9}$ The values for the portfolio of small device firms were large and statistically significant, producing a large and significant estimate for the overall device portfolio as well. Therefore, controlling for beta, small device firms "outperformed" the overall stock market during this period. The estimated average riskadjusted excess return for the small device firm portfolio was 1.6 percent per month.

\section{Fama-French Betas}

Table 4.4 shows F-F betas obtained from estimating equation 5 for the nine portfolios. The market betas were generally lower than those shown in Table 4.3, with the exception of the overall and large pharmaceutical betas for 2001-2005, which were larger than the CAPM beta estimates. The market betas for biotechnology firms again were significantly larger than those for pharmaceutical and device firms during 2001-2005, and those for biotechs and device firms were larger than for pharmaceutical firms during 2006-2008. The estimated alphas for device firms during 2001-2005 were again large and significant due to the small device firm portfolio.

The inclusion of the size and book-to-market factors in the returns equation produced relatively little increase in $R^{2}$ compared with the CAPM model. However, consistent with Golec and Vernon (2007) and Vernon et al. (2010), the size-factor beta estimates were positive and statistically significant for the small-firm portfolios for each sector and time period, and in some cases this caused the size-factor beta to be positive and significant for the overall sector portfolio. Therefore, smaller pharmaceutical, biotech, and device stock returns were correlated with those of other small firms during these time periods. The large pharmaceutical firm portfolio had a negative and statistically significant size beta during 2001-2005.

(p. 91) (p. 92) The book-to-market betas were negative, large in absolute value, and significantly different from zero for the overall and large biotech portfolios during 20012005. This result suggests that, after controlling for overall market returns, biotech stock returns tracked those of growth stocks during this time period, when average biotech R\&D intensity was high. However, the statistically significant and negative book-tomarket betas for biotechs did not persist in 2006-2008, when the larger biotechs had matured with greater sales and lower R\&D intensity. 
Table 4.4 Fama-French model parameter estimates for equal-weighted sector/size-based portfolios

2001-2005

\begin{tabular}{|c|c|c|c|c|c|c|c|c|c|c|}
\hline Group & $\widehat{\alpha}_{j, F F}$ & $\hat{\beta}_{j, M K T-R F}$ & $\hat{\beta}_{j, S M B}$ & $\hat{\beta}_{j, H M L}$ & R-sq. & $\widehat{\alpha}_{j, F F}$ & $\hat{\beta}_{j, M K T-R F}$ & $\hat{\beta}_{j, \mathrm{SMB}}$ & $\hat{\beta}_{j, H M L}$ & $R$-sq. \\
\hline $\begin{array}{l}\text { Pharmac } \\
\text { eutical }\end{array}$ & $\begin{array}{l}0.005 \\
(0.377)\end{array}$ & $\begin{array}{l}0.724 \\
(0.000)\end{array}$ & $\begin{array}{l}-0.115 \\
(0.520)\end{array}$ & $\begin{array}{l}0.022 \\
(0.907)\end{array}$ & $40.1 \%$ & $\begin{array}{l}-0.000 \\
(0.928)\end{array}$ & $\begin{array}{l}0.583 \\
(0.000)\end{array}$ & $\begin{array}{l}0.236 \\
(0.315)\end{array}$ & $\begin{array}{l}-0.172 \\
(0.315)\end{array}$ & $53.9 \%$ \\
\hline Large & $\begin{array}{l}0.003 \\
(0.579)\end{array}$ & $\begin{array}{l}0.771 \\
(0.000)\end{array}$ & $\begin{array}{l}-\mathbf{0 . 4 4 0} \\
(\mathbf{0 . 0 2 0})\end{array}$ & $\begin{array}{l}0.085 \\
(0.660)\end{array}$ & $39.7 \%$ & $\begin{array}{l}-0.001 \\
(0.869)\end{array}$ & $\begin{array}{l}0.643 \\
(0.000)\end{array}$ & $\begin{array}{l}-0.009 \\
(0.966)\end{array}$ & $\begin{array}{l}-0.001 \\
(0.966)\end{array}$ & $59.3 \%$ \\
\hline Small & $\begin{array}{l}0.009 \\
(0.279)\end{array}$ & $\begin{array}{l}\mathbf{0 . 6 0 8} \\
(\mathbf{0 . 0 0 4 )}\end{array}$ & $\begin{array}{l}0.679 \\
(0.015)\end{array}$ & $\begin{array}{l}-0.132 \\
(0.641)\end{array}$ & $33.4 \%$ & $\begin{array}{l}0.000 \\
(0.963)\end{array}$ & $\begin{array}{l}0.404 \\
(0.078)\end{array}$ & $\begin{array}{l}0.970 \\
(0.050)\end{array}$ & $\begin{array}{l}-0.692 \\
(0.166)\end{array}$ & $26.4 \%$ \\
\hline $\begin{array}{l}\text { Biotechn } \\
\text { ology }\end{array}$ & $\begin{array}{l}0.005 \\
(0.588)\end{array}$ & $\begin{array}{l}1.068 \\
(\mathbf{0 . 0 0 0 )}\end{array}$ & $\begin{array}{l}0.215 \\
(0.452)\end{array}$ & $\begin{array}{c}-\mathbf{0 . 6 2 0} \\
(\mathbf{0 . 0 4 1 )}\end{array}$ & $50.8 \%$ & $\begin{array}{l}0.007 \\
(0.254)\end{array}$ & $\begin{array}{l}\mathbf{0 . 8 6 9} \\
(\mathbf{0 . 0 0 0 )}\end{array}$ & $\begin{array}{l}\mathbf{0 . 6 8 4} \\
(\mathbf{0 . 0 3 1})\end{array}$ & $\begin{array}{l}-0.051 \\
(0.872)\end{array}$ & $64.3 \%$ \\
\hline Large & $\begin{array}{l}0.006 \\
(0.492)\end{array}$ & $\begin{array}{l}1.043 \\
(0.000)\end{array}$ & $\begin{array}{l}-0.020 \\
(0.949)\end{array}$ & $\begin{array}{c}-0.795 \\
(0.015)\end{array}$ & $47.6 \%$ & $\begin{array}{l}0.001 \\
(0.860)\end{array}$ & $\begin{array}{l}0.721 \\
(0.000)\end{array}$ & $\begin{array}{l}0.185 \\
(0.486)\end{array}$ & $\begin{array}{l}0.067 \\
(0.804)\end{array}$ & $57.2 \%$ \\
\hline Small & $\begin{array}{l}0.002 \\
(0.872)\end{array}$ & $\begin{array}{l}1.115 \\
(0.000)\end{array}$ & $\begin{array}{l}\mathbf{0 . 6 6 0} \\
(0.039)\end{array}$ & $\begin{array}{l}-0.290 \\
(0.376)\end{array}$ & $47.9 \%$ & $\begin{array}{l}0.013 \\
(0.147)\end{array}$ & $\begin{array}{l}1.008 \\
(0.000)\end{array}$ & $\begin{array}{l}1.149 \\
(0.012)\end{array}$ & $\begin{array}{l}-0.161 \\
(0.718)\end{array}$ & $58.7 \%$ \\
\hline
\end{tabular}




\begin{tabular}{|c|c|c|c|c|c|c|c|c|c|c|}
\hline Device & $\begin{array}{l}0.009 \\
(0.023)\end{array}$ & $\begin{array}{l}0.639 \\
(0.000)\end{array}$ & $\begin{array}{l}\mathbf{0 . 3 8 7} \\
(\mathbf{0 . 0 0 2 )}\end{array}$ & $\begin{array}{l}0.178 \\
(0.163)\end{array}$ & $60.3 \%$ & $\begin{array}{l}0.005 \\
(0.156)\end{array}$ & $\begin{array}{l}0.781 \\
(0.000)\end{array}$ & $\begin{array}{l}0.614 \\
(0.001)\end{array}$ & $\begin{array}{l}0.338 \\
(0.056)\end{array}$ & $84.1 \%$ \\
\hline Large & $\begin{array}{l}0.005 \\
(0.300)\end{array}$ & $\begin{array}{l}\mathbf{0 . 6 8 5} \\
(\mathbf{0 . 0 0 0 )}\end{array}$ & $\begin{array}{l}-0.125 \\
(0.416)\end{array}$ & $\begin{array}{l}0.158 \\
(0.320)\end{array}$ & $42.2 \%$ & $\begin{array}{l}0.002 \\
(0.691)\end{array}$ & $\begin{array}{l}0.788 \\
(0.000)\end{array}$ & $\begin{array}{l}0.196 \\
(0.347)\end{array}$ & $\begin{array}{l}0.418 \\
(0.056)\end{array}$ & $73.4 \%$ \\
\hline Small & $\begin{array}{l}\mathbf{0 . 0 1 0} \\
(0.029)\end{array}$ & $\begin{array}{l}0.622 \\
(0.000)\end{array}$ & $\begin{array}{l}0.579 \\
(0.000)\end{array}$ & $\begin{array}{l}0.185 \\
(0.230)\end{array}$ & $55.4 \%$ & $\begin{array}{l}0.007 \\
(0.078)\end{array}$ & $\begin{array}{l}0.778 \\
(0.000)\end{array}$ & $\begin{array}{l}\mathbf{0 . 8 4 7} \\
(\mathbf{0 . 0 0 0 )}\end{array}$ & $\begin{array}{l}0.293 \\
(0.124)\end{array}$ & $83.4 \%$ \\
\hline
\end{tabular}

Note: The regression equation is $R_{j t}-R_{F t}=\alpha_{j, F F}+\beta_{j, M K T-R F}\left(R_{M t}-R_{F t}\right)+\beta_{j, S M B}\left(R_{S t}-R_{B t}\right)+\beta_{j, H M L}\left(R_{H t}-R_{L t}\right)+\varepsilon_{j t}$. Subsamples include firms in the sector with market value of equity above (Large) or below (Small) the median value for all sample firms at the beginning of the sample period. Two-tailed $p$ values are shown in parentheses. Bold values are significant at the 0.05 level. 


\section{Cost of Equity Capital Estimates}

In Table 4.5, the CAPM and F-F beta estimates from Tables 4.3 and 4.4 and their estimated variances and covariances were used to generate (nominal) cost of equity capital estimates and 95 percent confidence intervals for those estimates. The estimates assume a risk-free rate of 5 percent per year, which corresponds to an expected annual real return on short-term Treasury bills of 2 percent plus an expected inflation rate of 3 percent. ${ }^{10}$ Cost of equity capital estimates for a different riskless rate could be obtained by simple addition or subtraction from those shown. The assumed market risk premium wasis 7 percent, which is approximately equal to the average annualized monthly excess market return available from CRSP during July 1926-June 2009 (7.1 percent). The expected excess return on small versus large stocks is assumed to be 3 percent, compared with an average annualized excess return on the F-F size portfolio of 2.8 percent during that period. The expected excess return on high book-to-market versus low book-to-market stocks was assumed to be 4 percent. This is 1 percent (100 basis points) lower than the average annualized excess return on the F-F book-to-market factor portfolio from July 1926 to June 2009, but it is more in line with the average return on that portfolio since the mid-1980s.

Given these assumptions, the point estimates of the (nominal) cost of equity capital based on the 2001-2005 CAPM betas were approximately 10 percent for pharmaceutical and device firms and 14 percent for the more R\&D-intensive and higher-beta biotechnology firms. For 2006-2008, the CAPM-based cost of equity capital estimates were approximately 9 percent for pharmaceuticals, 11 percent for device firms, and 12 percent for biotechs. For biotechs during 2006-2008, the estimated cost of equity was 13 percent for the higher-beta and more R\&D-intensive small firms compared with 10 percent for larger biotechs.

For the F-F model, the estimated cost of equity capital values for pharmaceutical firms were similar to those obtained from the CAPM in both time periods. During 2001-2005, the lower F-F market beta for small pharmaceutical firms compared with the CAPM basically offsets the effects of the positive size beta for small (p. 93) firms; likewise, the higher F-F market beta for large pharmacetical firms offsets the negative size beta for large firms (see Table 4.4). A similar offset affects the estimated cost of equity for small pharmaceutical firms for 2006-2008. Due primarily to the positive size betas for small device firms, the F-F cost of equity values for device firms were about 1 to 2 percent higher than those obtained with the CAPM for 2001-2006 and 2 to 3 percent higher for 2006-2008 (in part because of positive albeit insignificant book-to-market betas). 
Table 4.5 Illustrative cost of capital estimates by sector and group*

\section{1-2005}

\begin{tabular}{|c|c|c|c|c|c|c|c|c|}
\hline Model & Sector & Group & $\hat{k}$ & $\hat{k}_{0.025}$ & $\hat{k}_{0.975}$ & $\hat{k}$ & $\hat{k}_{0.025}$ & $\hat{k}_{0.975}$ \\
\hline \multirow[t]{9}{*}{ CAPM } & $\begin{array}{l}\text { Pharmaceu } \\
\text { tical }\end{array}$ & All & $9.8 \%$ & $8.3 \%$ & $11.4 \%$ & $9.3 \%$ & $7.8 \%$ & $10.7 \%$ \\
\hline & & Large & $9.6 \%$ & $7.8 \%$ & $11.3 \%$ & $9.5 \%$ & $8.2 \%$ & $10.8 \%$ \\
\hline & & Small & $10.6 \%$ & $8.1 \%$ & $13.1 \%$ & $8.6 \%$ & $5.5 \%$ & $11.8 \%$ \\
\hline & $\begin{array}{l}\text { Biotechnol } \\
\text { ogy }\end{array}$ & All & $14.2 \%$ & $11.6 \%$ & $16.9 \%$ & $11.8 \%$ & $9.8 \%$ & $13.7 \%$ \\
\hline & & Large & $14.1 \%$ & $11.3 \%$ & $16.9 \%$ & $10.2 \%$ & $8.6 \%$ & $11.9 \%$ \\
\hline & & Small & $14.5 \%$ & $11.6 \%$ & $17.3 \%$ & $13.2 \%$ & $10.3 \%$ & $16.1 \%$ \\
\hline & Device & All & $9.6 \%$ & $8.5 \%$ & $10.8 \%$ & $11.2 \%$ & $9.9 \%$ & $12.5 \%$ \\
\hline & & Large & $9.2 \%$ & $7.9 \%$ & $10.6 \%$ & $10.9 \%$ & $9.5 \%$ & $12.2 \%$ \\
\hline & & Small & $9.8 \%$ & $8.3 \%$ & $11.2 \%$ & $11.4 \%$ & $9.9 \%$ & $12.9 \%$ \\
\hline
\end{tabular}




\begin{tabular}{|c|c|c|c|c|c|c|c|c|}
\hline \multirow[t]{9}{*}{ F-F } & $\begin{array}{l}\text { Pharmaceu } \\
\text { tical }\end{array}$ & All & $9.8 \%$ & $6.9 \%$ & $12.7 \%$ & $9.1 \%$ & $6.7 \%$ & $11.5 \%$ \\
\hline & & Large & $9.4 \%$ & $6.4 \%$ & $12.4 \%$ & $9.5 \%$ & $7.3 \%$ & $11.6 \%$ \\
\hline & & Small & $10.8 \%$ & $6.3 \%$ & $15.2 \%$ & $8.0 \%$ & $3.1 \%$ & $12.8 \%$ \\
\hline & $\begin{array}{l}\text { Biotechnol } \\
\text { ogy }\end{array}$ & All & $10.6 \%$ & $6.0 \%$ & $15.3 \%$ & $12.9 \%$ & $9.8 \%$ & $16.0 \%$ \\
\hline & & Large & $9.1 \%$ & $4.0 \%$ & $14.1 \%$ & $10.9 \%$ & $8.2 \%$ & $13.6 \%$ \\
\hline & & Small & $13.6 \%$ & $8.5 \%$ & $18.8 \%$ & $14.9 \%$ & $10.5 \%$ & $19.2 \%$ \\
\hline & Device & All & $11.3 \%$ & $9.4 \%$ & $13.3 \%$ & $13.7 \%$ & $12.0 \%$ & $15.4 \%$ \\
\hline & & Large & $10.1 \%$ & $7.6 \%$ & $12.6 \%$ & $12.8 \%$ & $10.7 \%$ & $14.9 \%$ \\
\hline & & Small & $11.8 \%$ & $9.4 \%$ & $14.2 \%$ & $14.2 \%$ & $12.3 \%$ & $16.0 \%$ \\
\hline
\end{tabular}

Abbreviations: CAPM, capital asset pricing model; F-F, Fama and French model.

(*) The estimated costs of capital for the CAPM and FF models are $\hat{k}_{j, \mathrm{CAPM}}=0.05+0.07 \hat{\beta}_{\text {, CAPM }}$ and $\hat{k}_{j, F F}=0.05+0.07 \hat{\beta}_{j, M K T-R F}+0.03 \hat{\beta}_{j, S M L}+0.04 \hat{\beta}_{j, H M L}$. The statistics $\hat{k}_{0.025}$ and $\hat{k}_{0.975}$ represent the $95 \%$ confidence interval for $\hat{k}$. 
Given the large and negative book-to-market betas for large biotechs during 2001-2005, the estimated cost of equity for large biotechs using the F-F model during that period was much lower (9.1 percent) than the value obtained using (p. 94) the CAPM (14.1 percent). However, the disappearance of the relationship between biotechnology firm returns and book-to-market factor returns during 2006-2008 caused the cost of equity capital estimates for large biotechs to converge for the two models (10.9 percent for the F-F model and 10.2 percent for the CAPM).

\section{Individual Firm Betas and R\&D Intensity}

Individual firm CAPM and F-F beta estimates were also obtained using equations 2 and 3 for the 2001-2005 and 2006-2008 samples. In order to provide evidence of the relationship between beta estimates, sector, $R \& D$ intensity, and firm size (market capitalization), the following cross-sectional regression model was estimated for each beta estimate and period: (6)

$$
\begin{aligned}
\hat{\beta}_{j, l}= & a_{0}+a_{1} \text { Biotech }_{j}+a_{2} \text { Device }_{j}+a_{3} R \& \text { D/Sales } \\
& +a_{4} \text { Log Market Equity }_{j}+e_{j}
\end{aligned}
$$

where $l=C A P M, M K T-R F$ (the difference between the expected return of the market and a risk-free asset), SML (the difference in the expected return of small and large stocks), or HML (the difference in the expected return of high book-to-market stocks and low book-to-market stocks); Biotech and Device are sector indicators; R\&D/Sales is the firm's average ratio of $R \& D$ expense to sales for the period (again truncated at 1 ); and $\mathrm{Log}$ Market Equity is the log of the firm's market value of equity at the beginning of the sample period. Similar results to those reported here were obtained when indicators were included for generic pharmaceutical firms, for foreign-owned (or American Depository Receipt [ADR]) firms, and when the average ratio of long-term debt to value was included. None of the additional variables was significantly related to the estimated betas. Results with similar implications also were obtained by estimating models (without sector indicators) separately for each sector.

Table 4.6 shows bivariate correlations between the beta estimates, R\&D intensity, log market equity, and long-term debt/value. As expected, R\&D intensity was positively and significantly related to both CAPM and F-F market betas each period. It was negatively and significantly related to F-F book-to-market betas in 2001-2005. Again as expected, log market equity was negatively and significantly related to the F-F size betas.

Table 4.7 shows least squares estimates of equation 6 for each beta estimate and time period (with heteroskedasticity robust standard errors in parentheses). For the CAPM and F-F market betas, the estimates for the biotechnology and device indicators are 
consistent with the findings of the portfolio analysis, except that the (p. 95) coefficient for the biotech indicator was not statistically significant during 2006-2008. The CAPM and FF market betas were positively and significantly related to $R \& D$ intensity in both periods. The coefficient on R\&D intensity was 1.17 for the CAPM beta and 0.83 for the F-F market beta for 2001-2005. The coefficients were approximately 1 for both market beta measures for 2006-2008. Given an expected market risk premium of 7 percent, a coefficient for R\&D intensity of 1 implies that, other factors being held constant, the cost of equity capital would increase 0.7 percent ( 70 basis points) for every increase of 10 percentage points in $R \& D$ intensity. 
Table 4.6 Bivariate correlations: betas, R\&D/sales, log market equity, and long-term debt/value*

\begin{tabular}{|c|c|c|c|c|c|c|c|c|}
\hline Period & Indicator & $\hat{\beta}_{j, C A P M}$ & $\hat{\beta}_{j, M K T-R F}$ & $\hat{\beta}_{j, S M B}$ & $\hat{\beta}_{j, H M L}$ & R\&D/Sales & $\begin{array}{l}\text { Log } \\
\text { Market } \\
\text { Equity }\end{array}$ & $\begin{array}{l}\text { Long- } \\
\text { Term } \\
\text { Debt/ } \\
\text { Value }\end{array}$ \\
\hline \multirow[t]{7}{*}{ 2001-2005 } & $\hat{\beta}_{j, C A P M}$ & 1.00 & & & & & & \\
\hline & $\hat{\beta}_{j, M K T-R F}$ & 0.89 & 1.00 & & & & & \\
\hline & $\hat{\beta}_{j, S M B}$ & 0.21 & 0.00 & 1.00 & & & & \\
\hline & $\hat{\beta}_{j, H M L}$ & -0.43 & -0.06 & 0.11 & 1.00 & & & \\
\hline & R\&D/Sales & 0.63 & 0.47 & 0.01 & -0.53 & 1.00 & & \\
\hline & $\begin{array}{l}\text { Log Market } \\
\text { Equity }\end{array}$ & -0.11 & 0.07 & -0.70 & -0.04 & 0.00 & 1.00 & \\
\hline & $\begin{array}{l}\text { Long-Term } \\
\text { Debt/Value }\end{array}$ & 0.09 & 0.15 & 0.20 & 0.22 & 0.03 & -0.04 & 1.00 \\
\hline
\end{tabular}




\begin{tabular}{|c|c|c|c|c|c|c|c|c|}
\hline \multirow[t]{7}{*}{ 2006-2008 } & $\hat{\beta}_{j, C A P M}$ & 1.00 & & & & & & \\
\hline & $\hat{\beta}_{j, M K T-R F}$ & 0.96 & 1.00 & & & & & \\
\hline & $\hat{\beta}_{j, S M B}$ & 0.10 & -0.17 & 1.00 & & & & \\
\hline & $\hat{\beta}_{j, H M L}$ & 0.01 & -0.05 & -0.04 & 1.00 & & & \\
\hline & R\&D/Sales & 0.41 & 0.36 & 0.19 & -0.16 & 1.00 & & \\
\hline & $\begin{array}{l}\text { Log Market } \\
\text { Equity }\end{array}$ & $-\mathbf{0 . 3 0}$ & -0.18 & -0.44 & 0.06 & -0.15 & 1.00 & \\
\hline & $\begin{array}{l}\text { Long-Term } \\
\text { Debt/Value }\end{array}$ & 0.04 & 0.04 & -0.03 & 0.19 & -0.03 & -0.07 & 1.00 \\
\hline
\end{tabular}

(*) Bold values are significant at the 0.05 level for two-tailed test. 
The F-F size betas were negatively and significantly related to log market equity for each period, with estimated coefficients of -0.31 and -0.22 for 2001-2005 and 2006-2008, respectively. Using a 3 percent size factor premium and the -0.22 estimate, an increase in market capitalization at the beginning of 2006 from (p. 96) (p. 97) \$948 million (approximately the 25th percentile value for the 2006-2008 sample) to $\$ 16.2$ billion (approximately the 75th percentile) would increase the estimated cost of equity by 1.9 percent (190 basis points). 
Table 4.7 Cross-sectional determinants of CAPM and F-F beta estimates

\section{1-2005 (100 co.)}

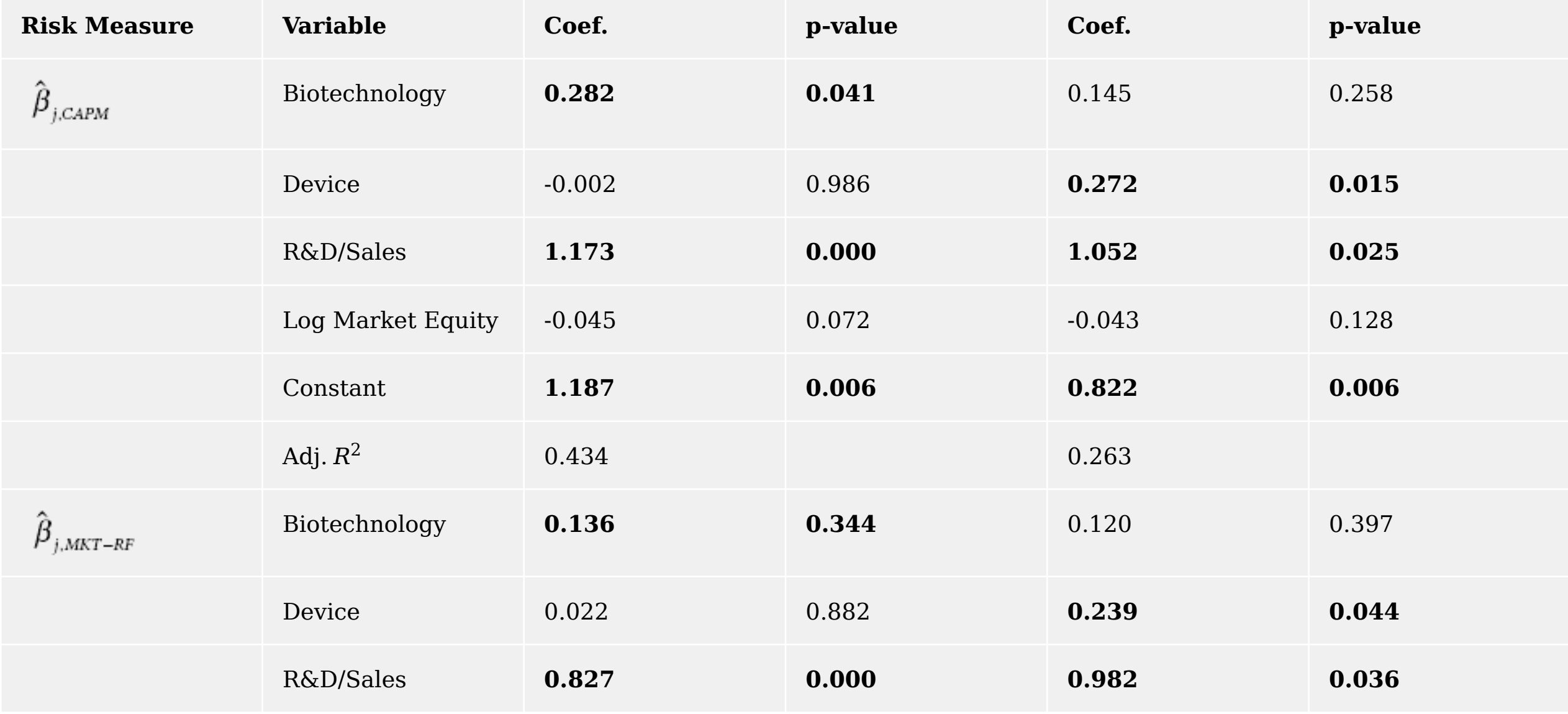

\section{Page 32 of 40}

PRINTED FROM OXFORD HANDBOOKS ONLINE (www.oxfordhandbooks.com). (c) Oxford University Press, 2015. All Rights Reserved. Under the terms of the licence agreement, an individual user may print out a PDF of a single chapter of a title in Oxford Handbooks Online for personal use (for details see Privacy Policy). 


\begin{tabular}{|c|c|c|c|c|c|}
\hline & Log Market Equity & 0.019 & 0.503 & -0.013 & 0.659 \\
\hline & Constant & 0.274 & 0.585 & 0.556 & 0.083 \\
\hline & Adj. $R^{2}$ & 0.237 & & 0.176 & \\
\hline \multirow[t]{6}{*}{$\hat{\beta}_{j, S M B}$} & Biotechnology & 0.193 & 0.211 & 0.092 & 0.694 \\
\hline & Device & -0.032 & 0.829 & 0.026 & 0.909 \\
\hline & R\&D/Sales & -0.157 & 0.478 & 0.535 & 0.240 \\
\hline & Log Market Equity & -0.305 & $\mathbf{0 . 0 0 0}$ & -0.222 & $\mathbf{0 . 0 0 0}$ \\
\hline & Constant & 4.715 & $\mathbf{0 . 0 0 0}$ & 2.223 & 0.000 \\
\hline & Adj. $R^{2}$ & 0.504 & & 0.212 & \\
\hline \multirow[t]{4}{*}{$\hat{\beta}_{j, H M L}$} & Biotechnology & -0.318 & 0.114 & 0.267 & 0.257 \\
\hline & Device & 0.051 & 0.770 & 0.646 & 0.013 \\
\hline & R\&D/Sales & -1.144 & $\mathbf{0 . 0 0 0}$ & -0.246 & 0.568 \\
\hline & Log Market Equity & -0.002 & 0.961 & 0.087 & 0.114 \\
\hline
\end{tabular}




\begin{tabular}{|c|c|c|c|c|}
\hline Constant & 0.254 & 0.680 & -0.945 & 0.128 \\
\hline $\operatorname{Adj} . R^{2}$ & 0.306 & & 0.107 & \\
\hline
\end{tabular}

Abbreviations: Adj. $R^{2}$, adjusted coefficient of determination; CAPM, capital asset pricing model; F-F, Fama and French model.

Note: Bold values are significant at the 0.05 level for a two-tailed test with robust standard errors. 
Consistent with the portfolio results, there was a strong, negative relationship between FF book-to-market betas and R\&D intensity during 2001-2005, but the estimated coefficient for R\&D intensity was much closer to zero and insignificant for the 2006-2008 sample. The coefficient for the device indicator in the book-to-market beta equation was positive and significant for 2006-2008. Other factors held constant, the magnitude of the coefficient, along with a 4 percent book-to-market factor risk premium, would imply a 2.5 percent (250 basis) point higher cost of equity for device firms than for pharmaceutical firms. The explanation of this result (assuming that it is not spurious) is not clear. ${ }^{11}$ It reflects in part the negative (albeit statistically insignificant) estimated beta for pharmaceutical firms during 2006-2008 (see Table 4.4).

\section{Conclusions}

This study provides estimates of systematic risk and the cost of equity capital for the pharmaceutical, biotechnology, and medical device sectors using data for firms with publicly traded stock on US exchanges (including foreign owned-firms) and market capitalization of at least \$100 million during 2001-2005 and 2006-2008 using the CAPM model and F-F three-factor model. It also provides evidence of the relationship between firms' systematic risk, cost of equity, and intensity of $R \& D$ expenditures.

There are four principal findings. First, $R \& D$ intensity, as measured by the ratio of $R \& D$ expense to sales, is positively related to market betas and thus to the estimated cost of equity capital, after controlling for firms' principal sector of operations (pharmaceutical, biotechnology, or device). Second, the choice of model matters. The CAPM and F-F models can produce materially different estimates of the cost of equity capital. In particular, and consistent with other work, the F-F model results imply a size-related risk premium in the cost of equity for small firms in each sector. Third, after controlling for $R \& D$ intensity, average market betas can differ significantly across sectors. Biotech firms had significantly higher market betas than pharmaceutical firms during 2001-2005, and device firms had significantly higher betas than pharmaceutical firms during 2006-2008. Fourth, the time period matters, as implied by the preceding results and by the large negative and (p. 98) significant book-to-market beta for large biotech firms during 20012005, which significantly lowered the estimated cost of capital during that period but did not persist during 2006-2008.

These results have potentially important implications for valuation and capital budgeting of pharmaceutical, biotechnology, and device firms. They raise the possibility of obtaining better estimates of a firm's cost of equity using on the cross-sectional relationship between risk and R\&D intensity. They also suggest the possible value, in practice, of comparing values of projects based on estimates of the cost of capital using the CAPM and F-F models, at least for small firms. The cost of equity capital will usually be higher 
on average for smaller publicly-traded firms and for privately held firms than for the samples analyzed in this study due higher R\&D intensity and illiquidity.

Along with theory and prior work, this study's results concerning risk and R\&D intensity also highlight the question of whether a time-varying discount rate should be used to value molecules or devices in different stages of development. Although technical (scientific) risk is likely diversifiable by investors, early-stage projects have greater R\&D intensity and thus greater systematic risk. The return required by investors is therefore likely to be greater than for late-stage projects. If a constant discount rate is used to value all expected future cash flows based on a firm's overall cost of capital, early-stage projects will tend to be overvalued and late-stage projects will tend to be undervalued. Additional work is needed to determine whether and how time-varying discount rates could be employed in practice.

\section{References}

Bastin, V., and G. Hubner. 2006. "Concentrated Announcements on Clustered Data: An Event Study of Biotechnology Stocks.” Financial Management 35: 129-157.

Berk, J., R. Green, and V. Naik. 2004. "Valuation and Return Dynamics of New Ventures." The Review of Financial Studies 17: 1-35.

Chan, K., J. Lakonishok, and T. Sougiannis. 2001. "The Stock Market Valuation of Research and Development Expenditures." Journal of Finance 56: 2431-2456.

Clem, A., A. Cowan, and C. Jeffrey. 2004. "Market Reaction to Proposed Changes in Accounting for Purchased Research and Development in R\&D-Intensive Industries." Journal of Accounting, Auditing \& Finance: 19(4): 405-428.

Cochrane, J. 2001. Asset Pricing. Princeton, NJ: Princeton University Press.

Cockburn, I., and J. Lerner. 2009. The Cost of Capital for Early-Stage Biotechnology Ventures. Boston University and Harvard University. Available at http:// www.slideshare.net/NVCA/the-cost-of-capital-for-early-stage-biotechnologyventures (accessed November 2011).

DiMasi, J., and H. Grabowski. 2007. "The Cost of Biopharmaceutical R\&D: Is Biotech Different?" Managerial and Decision Economics 28: 469-479.

DiMasi, J., R. Hansen, and H. Grabowski. 2003. "The Price of Innovation: New Estimates of Drug Development Costs.” Journal of Health Economics 22: 151-185.

DiMasi, J., R. Hansen, H. Grabowski, and L. Lasagna. 1991. "Cost of Innovation in the Pharmaceutical Industry.” Journal of Health Economics 10: 107-142. 
(p. 99) Eberhart, A., W. Maxwell, and A. Siddique. 2004. "An Examination of Long-Term Stock Returns and Operating Performance Following R\&D Increases." Journal of Finance 59: 623-650.

Fama, E., and K. French. 1992. "The Cross-section of Expected Stock Returns.” Journal of Finance 47: 427-455.

Fama, E., and K. French. 1993. "Common Risk Factors in Returns on Stocks and Bonds." Journal of Financial Economics 33: 3-56.

Fama, E., and K. French. 2006. "The Value Premium and the CAPM.” Journal of Finance 61: 2163-2185.

Ellison, S., and W. Mullin. 2001. "Gradual Incorporation of Information: Pharmaceutical Stocks and the Evolution of President Clinton's Health Care Reform." Journal of Law \& Economics 44: 89-129.

Golec, J., S. Hegde, and J. Vernon. 2005. Pharmaceutical Stock Price Reactions to Price Constraint Threats and Firm-Level R\&D Spending. NBER Working Paper 11229.

Cambridge, MA: National Bureau of Economic Research.

Golec, J., and J. Vernon. 2007. “Financial Risk in the Biotechnology Industry.” NBER

Working Paper 13604. Cambridge, MA: National Bureau of Economic Research.

Grabowski, H., and J. Vernon. 1990. "A New Look at the Returns and Risks of Pharmaceutical R\&D." Management Science 36: 804-821.

Hand, J. 2004. "The Market Valuation of Biotechnology Firms and Biotechnology R\&D.” In Venture Capital Contracting and the Valuation of High-Technology Firms, eds. J. McCahery and L. Renneboog. Oxford, UK: Oxford University Press: 251-280.

Healy, P., S. Myers, and C. Howe. 2002. "R\&D Accounting and the Tradeoff Between Relevance and Objectivity.” Journal of Accounting Research 40: 677-710.

Joos, P. 2002. Estimating Cross-sectional Differences in Market-to-Book Ratios in the Pharmaceutical Industry. Working paper. Rochester, NY: William E. Simon Graduate School of Business Administration, University of Rochester.

Lev, B., and T. Sougiannis. 1999. "Penetrating the Book-to-Market Black Box: The R\&D Effect." Journal of Business Finance \& Accounting 26: 419-449.

Sougiannis, T., B. Lev, and B. Sarath. 2005. “R\&D Reporting Biases and their Consequences." Contemporary Accounting Research 22: 977-1026.

McNamara, P., and C. Baden-Fuller. 2007. "Shareholder Returns and the ExplorationExploitation Dilemma: R\&D Announcements by Biotechnology Firms." Research Policy 36: 548-565. 
Myers, S., and Howe, C. 1997. A Life-Cycle Financial Model of Pharmaceutical R\&D. Working paper. Cambridge, MA: Program on the Pharmaceutical Industry, Sloan School of Management, Massachusetts Institute of Technology.

Myers, S., and L. Shyam-Sunder. 1996. "Measuring Pharmaceutical Industry Risk and the Cost of Capital." In Competitive Strategies in the Pharmaceutical Industry, ed. R. Helms. Washington, DC: American Enterprise Institute: 208-237.

Passov, R. 2003. “How Much Cash Does Your Company Need?” Harvard Business Review 81 (November): 1-8.

US Congress, Office of Technology Assessment. 1993. Pharmaceutical R\&D: Costs, Risks and Rewards. OTA-H-522. Washington, DC: US Government Printing Office.

van Dijk, M. In press. "Is Size Dead? A Review of the Size Effect in Equity Returns." Journal of Banking \& Finance. Available at SSRN: http://ssrn.com/abstract=879282 (accessed November 2011).

Vernon, J., J. Golec, and J. DiMasi. 2010. “Drug Development Costs When Financial Risk is Measured Using the Fama-French Three-Factor Model." Health Economics Letters 19(8): 1002-1005.

\section{Notes:}

(1.) Also see Cockburn and Lerner (2009), which discusses and cites high betas for earlystage ventures. A variety of studies have used the CAPM or F-F-based models in event studies of abnormal returns for pharmaceutical and biotechnology stocks (see, e.g., Bastin and Hubner 2006; Golec et al. 2005; McNamara and Baden-Fuller 2007).

(2.) Also see Ellison and Mullin (2001). In related research, studies of the relationship between R\&D intensity and equity values have considered whether stock prices accurately reflect intangible assets associated with R\&D. Chan et al. (2001), for example, analyzed the relation between historical stock returns and firms' R\&D. Eberhart et al. (2004) provided evidence of positive abnormal stock returns for firms with unexpected increases in R\&D. Lev and Sougiannis (1999) considered a possible relationship between $R \& D$ and the book-to-market phenomenon in stock returns. Other studies have considered possible valuation effects of the accounting treatment of R\&D. See, for example, Sougiannis et al. (2005); specific applications to the pharmaceutical and biotechnology sectors include Joos (2002), an empirical analysis of relations between pharmaceutical firms' book-to-market ratios and R\&D; Healy et al. (2002), a simulation analysis of relations between accounting treatment of $R \& D$ and a pharmaceutical firm's economic value; Hand (2004), an empirical analysis of the relation between market equity value and R\&D measures in biotechnology; and Clem et al. (2004), an examination of 
stock price reactions to proposed changes in accounting treatment of purchased inprocess $R \& D$ for $R \& D$-intensive firms.

(3.) See, for example, Cochrane (2001), Chapter 5.

(4.) The minimum market capitalization criterion was designed to reduce issues associated with infrequent trading. A handful of firms that met the other criteria were excluded on this basis.

(5.) Clinical research organizations and laboratories were excluded even if they reported some R\&D expense.

(6.) Classifying size groups based on the F-F size portfolio cutoffs would have produced too few small firms for meaningful analysis.

(7.) For regressions of betas on the ratio of $R \& D$ to sales, qualitatively similar results were obtained using the raw values of the variable.

(8.) The dearth of debt financing likely reflects a variety of influences, including (1) large amounts of intangible assets that might be threatened by financial instability, (2) lower marginal value of debt tax shields in the presence of tax shields arising from the immediate tax deductibility of R\&D expenditures, and (3) historically large generation of internal funds, which reduces the need for external financing. See Passov (2003) for further discussion.

(9.) The estimated alpha from equation (4), sometimes called "Jensen's alpha," is a common measure of risk-adjusted performance for portfolios and individual securities.

(10.) Myers and Shyam-Sunder (1996) employed a projected 20-year Treasury rate less the average term premium compared with Treasury bills to serve as a proxy for the riskless rate for long-duration $R \& D$ investments.

(11.) Although higher CAPM betas for device companies than for pharmaceutical firms during 2006-2008 could reflect greater price elasticity of demand for devices, it is not clear why greater price elasticity would lead to higher book-to-market betas in the F-F framework. 


\section{Scott E. Harrington}

Scott E. Harrington is Alan B. Miller Professor in the Health Care Management and Insurance and Risk Management departments at the Wharton School of the University of Pennsylvania. He is an adjunct scholar for health policy at the American Enterprise Institute. A former president of both the American Risk and Insurance Association and the Risk Theory Society, he is a coeditor of the Journal of Risk and Insurance and has published widely on financial risk assessment, risk management, and the economics and regulation of insurance. A frequent speaker on insurance markets, regulation, and public policy, he has conducted research, consulted, or served as an expert for many organizations. He has testified before the US House of Representatives and the Senate and before numerous US state legislative and administrative committees. He currently teaches classes on health care financial management, health policy, and health care econometrics. 